\title{
Increase of Metal Accumulation in Plants Grown on Biochar - Biochar Ecotoxicity for Germinating Seeds
}

\author{
P. Soudek, Š. Petrová, and T. Vaněk
}

\begin{abstract}
The effect of toxic metals on seed germination was studied in 3 cultivars of sorghum (Sorghum bicolor L.). Toxicity of cadmium, copper, and lead at five different concentrations $(0.05-5 \mathrm{mM})$ was tested by standard ecotoxicity test. Three different biochars as supplement was used for the test. Root length was measured after $72 \mathrm{~h}$ of incubation. Elongation inhibition and $\mathrm{EC}_{50}$ value were calculated. The results showed that beech tree biochar was the most efficient to reduce the toxicity of tested heavy metal. It contained the highest PAHs content, lowest content of measured heavy metals and the lowest $\mathrm{pH}$ value from tested biochars.
\end{abstract}

Index Terms-Biochar, heavy metals, seeds germination, sorghum.

\section{INTRODUCTION}

The area of land contaminated with heavy metals has increased during the last century due to mining, smelting, manufacturing, urban and other industrial activities. Nowadays, heavy metals have a serious ecological impact due to their toxicity and accumulation. These elements can be leached into the surface water or groundwater, taken up by plants, released as gases into the atmosphere, or bound semi-permanently by soil components such as clay or organic matter, and later affect human health [1], [2].

Heavy metals represent high stress factor for environment and for human. Their toxicities are express in many different effects and they can be cause of indigestions, different dermatitis, changes in blood count, damage of fundamental organs (brain, liver, and kidney), cancerous processes etc. For majority of metal cations the strong binding with $-\mathrm{SH}$, $-\mathrm{COOH}$ and $-\mathrm{NH}_{2}$ groups are characteristic [3]. Therefore more important is the lowering of toxic metals on the natural level.

Root growth inhibition as a parameter of heavy metal toxicity for plants was tested by many authors. Reference [4] tested responses of root growth inhibition and photosynthetic pigments production of Sinapis alba on heavy metal treatment $\left(\mathrm{Cu}^{2+}, \mathrm{Ni}^{2+}, \mathrm{Mn}^{2+}, \mathrm{MoO}_{4}{ }^{2-}, \mathrm{VO}_{4}{ }^{3-}\right)$. The most toxic for root growth were $\mathrm{Cu}^{2+}$ and $\mathrm{MoO}_{4}{ }^{2-}$. In the next paper [5] and [6] were investigated metal-metal interactions in accumulation of same metal treatment as above. Lead uptake and effect on seed germination and plant growth in $\mathrm{Pb}$

Manuscript received May 20, 2014; revised August 28, 2014. This work was supported by Czech Ministry of Education, Youth and Sports project COST Action TD1107 (Project No. LD 13029).

P. Soudek, Š. Petrová, and T. Vaněk are with the Laboratory of Plant Biotechnologies, Institute of Experimental Botany AS CR, v.v.i., Rozvojová 263, 16502 Prague 6 - Lysolaje, Czech Republic (e-mail: soudek@ ueb.cas.cz). hyperaccumulator Brassica pekinensis Rupr. was reported [7]. They found $56.7 \%$ decreasing of germination rate at the concentration $1000 \mu \mathrm{g}$ of $\mathrm{Pb}$ per $\mathrm{mL}$ and also decreasing of root length. The inhibitory effects of $\mathrm{Cd}, \mathrm{Cu}, \mathrm{Zn}, \mathrm{Pb}$ and $\mathrm{Fe}$ on root elongation, contents of photosynthetic pigments, and metal accumulation in the roots and shoots of $S$. alba were tested [8]. Metals were arranged on the basis of growth inhibition in order $\mathrm{Cu}>\mathrm{Cd}>\mathrm{Fe}=\mathrm{Zn}>\mathrm{Pb}$. Reference [9] reported stimulation effect of $0.005 \mathrm{mg} / \mathrm{L}$ dose of tested heavy metals $\left(\mathrm{Cd}^{2+}, \mathrm{Cr}^{6+}, \mathrm{Cu}^{2+}, \mathrm{Ni}^{2+}\right.$ and $\left.\mathrm{Zn}^{2+}\right)$ on root and shoot elongation of alfalfa plant (cv. Malone). The dose of $0.04 \mathrm{mg} / \mathrm{L}$ of $\mathrm{Cd}^{2+}, \mathrm{Cr}^{6+}, \mathrm{Cu}^{2+}$ and $\mathrm{Ni}^{2+}$ significantly reduced the ability of the seed to germinate and growth in the medium with heavy metal treatment. Effect of metals on seed germination, root elongation and coleoptile and hypocotyl growth in Triticum aestivum and Cucumis sativus were also studied [10]. Mercury was determined to be the most inhibited metal under these parameters. This metal caused a complete inhibition of germination in wheat and cucumber seeds at certain concentrations: $\geq 1.5 \mathrm{mM}$ in cucumber and at $1.7 \mathrm{mM}$ in wheat.

The aim of the present work was to evaluate the effect of toxic metals in presence or absence of biochar on the germination of sorghum (Sorghum bicolor L.) seeds to select resistant cultivars for phytoremediation purposes.

\section{MATERIAL AND METHODS}

\section{A. Plant Material and Chemicals}

Three cultivars of S. bicolor L. (Expres, Honey Graze and Nutri Honey) seeds (obtained from SEED SERVICE s.r.o., Czech Republic) were used for the germination test. Heavy-metal ions $\left(\mathrm{Cd}^{2+}, \mathrm{Cu}^{2+}\right.$, and $\left.\mathrm{Pb}^{2+}\right)$ were obtained from salts $\mathrm{Cd}\left(\mathrm{NO}_{3}\right)_{2} \times \mathrm{H}_{2} \mathrm{O}, \mathrm{Cu}\left(\mathrm{NO}_{3}\right)_{2} \times 3 \mathrm{H}_{2} \mathrm{O}$, and $\mathrm{Pb}\left(\mathrm{NO}_{3}\right)_{2}$. Tested concentrations of each metal were $0.05,0.1,0.5,1$ and $5 \mathrm{mM}$. The biochar was used from beech tree (EKOGRILL Ltd., Czech Republic), rice husk or bamboo (Dr. Jing Song, Nanjing, China). All substances were dissolved in distilled water containing $2 \mathrm{mM} \mathrm{CaCl} 2 \times 2 \mathrm{H}_{2} \mathrm{O}, 0.5 \mathrm{mM} \mathrm{MgSO}_{4} \times$ $7 \mathrm{H}_{2} \mathrm{O}, 0.8 \mathrm{mM} \mathrm{NaHCO}$, and $0.08 \mathrm{mM} \mathrm{KCl}$ (according to ČSN EN ISO 7346) (all chemicals were from Penta [http://www.pentachemicals.eu]). The $\mathrm{pH}$ was adjusted to 7.6 by addition of $0.1 \mathrm{M}$ solution of $\mathrm{NaOH}$.

\section{B. Semichronic Toxicity Test}

The seeds were placed in plastic dishes (10-cm diameter) with a layer of a filter article on the bottom. To the half of Petri dishes was weighed $0.5 \mathrm{~g}$ of biochar. Seventeen seeds were equally placed into each dish on the surface of filter article, and $5 \mathrm{~mL}$ tested aqueous solution with heavy metal 
was added. Each treatment had four replicates. The exposure lasted for $72 \mathrm{~h}$ in the dark at $25^{\circ} \mathrm{C}$. Root lengths were measured, and inhibition values of root elongation were calculated according to the following equation (1):

$$
I=(D c-D t) / D c
$$

where $I$ is the inhibition of root elongation in $\% ; D c$ is the average length of root under control conditions (i.e., without heavy metal treatment) [mm]; and $D t$ is the average length of root grown under the tested metal concentration [mm].

\section{C. $E C_{50}$ Calculation}

$\mathrm{EC}_{50}$ is an effective concentration at which $50 \%$ of tested organisms have a significant response to the tested compound. For the purpose of calculation, nonlinear regression with the lower and upper maximum (0 and 100, respectively) was used. Data were processed by software GraphPad Prism (GraphPad, San Diego, CA), and the output was to MS Excel. The NOEC value is the highest tested concentration of a toxic compound at which there is no significant unfavorable impact on tested organisms compared with controls.

\section{Heavy Metal Determination}

Biochars were ground to a powder and samples $(\mathrm{Ca} 0.125$ g DW) were digested in $5 \mathrm{~mL}$ mixture $\mathrm{HClO}_{4} / \mathrm{HNO}_{3}$ $(15 / 85 \%, v / v)$ in digestion glass tubes overnight. Digestion was completed by gradual increase of temperature from 60 to $195^{\circ} \mathrm{C}$ according reference [11]. Digestion protocol was as follows: $3 \mathrm{~h}, 60^{\circ} \mathrm{C} ; 1 \mathrm{~h}, 100{ }^{\circ} \mathrm{C} ; 1 \mathrm{~h}, 120^{\circ} \mathrm{C} ; 3 \mathrm{~h}, 195{ }^{\circ} \mathrm{C}$. After cooling, $2.5 \mathrm{~mL} 20 \% \mathrm{HCl}$ was added, whirl mixed and warmed to $80^{\circ} \mathrm{C}$ for $1 \mathrm{~h}$. The final volume was brought to 10 $\mathrm{mL}$ accurately. Heavy metal content was measured by AAS (SensAA, GBS, Australia).

\section{E. pH Measurement}

The $\mathrm{pH}$ was determined on a 1:5 biochar / $0.01 \mathrm{M} \mathrm{CaCl}_{2}$ or biochar / distillate water suspension after 30 minutes of settling. Values of $\mathrm{pH}$ were determined by an UltraBasic $\mathrm{pH}$ Meter (Denver Instrument Company, USA).

\section{F. PAHs Extraction and Determination}

Biochar (4 g) together with anhydrous sodium sulfate (1 g) were placed in the Erlenmeyer flasks. They were extracted with $40 \mathrm{ml}$ dichloromethane at $25^{\circ} \mathrm{C}$ for $24 \mathrm{~h}$.

The dichloromethane solution was evaporated to almost dryness using rotary evaporator (400 mbar, $70 \mathrm{rpm}$, water bath temperature $35^{\circ} \mathrm{C}$ ) and then dissolved in $2 \mathrm{ml}$ cyclohexane. Wherein $1 \mathrm{ml}$ cyclohexane was cleaned up by silica gel column and eluted with acetone / hexane (1:1, v/v). About $4 \mathrm{ml}$ eluent was collected and subsequently evaporated to dryness under nitrogen gas. The PAHs were dissolved in 1 $\mathrm{ml}$ dichloromethane before HPLC analysis.

\section{G. Statistics}

Statistical analysis was performed based on STATISTICA (StatSoft, Tulsa, OK) software.

\section{RESUlTS AND DisCUSSION}

Biochar is, due to its ability of the sorption characteristics to reduce mobility and phytotoxicity certain organic and inorganic pollutants in the soil, able to eliminate limitations of phytoremediation. But the amount of information that relates to the application of biochar in order to improve efficiency of phytoextraction and phytostabilization is currently very limited. The main aim of this study is therefore to test biochar obtained from the pyrolysis of different biological sources on toxic residues and possible influence of biochar on germinated plants in presence of heavy metals.

TABLE I: METAL CONTENT IN BIOCHAR SAMPLES AND PH

\begin{tabular}{lllll}
\hline \hline & & Bamboo & Rice husk & Beech tree \\
\hline Metal $[\mu \mathrm{g} / \mathrm{g}]$ & $\mathrm{Cd}$ & n.d. & n.d. & n.d. \\
& $\mathrm{Zn}$ & 8.29 & 2.41 & 0.45 \\
& $\mathrm{Cu}$ & 0.61 & 0.65 & 0.32 \\
& $\mathrm{Fe}$ & 8.65 & 39.68 & 7.22 \\
$\mathrm{pH}$ & $\mathrm{Pb}$ & n.d. & n.d. & n.d. \\
& $\mathrm{H}_{2} \mathrm{O}$ & 9.50 & 10.00 & 8.69 \\
& $\mathrm{CaCl}_{2}$ & 9.19 & 9.36 & 8.21 \\
\hline \hline
\end{tabular}

TABLE II: PAH CONTENT IN BIOCHAR SAMPLES

\begin{tabular}{llll}
\hline \hline PAHs [ng/g] & Bamboo & Rice husk & Beech tree \\
\hline Naphthalene & 17.71 & 24.13 & 240.86 \\
Acenaphthylene & 0.00 & 0.00 & 0.00 \\
Acenaphthene & 0.00 & 0.00 & 8.59 \\
Fluorene & 24.62 & 62.42 & 58.87 \\
Phenanthrene & 34.25 & 199.71 & 211.04 \\
Anthracene & 6.17 & 37.71 & 22.97 \\
Fluoranthene & 3.20 & 6.84 & 63.82 \\
Pyrene & 40.26 & 17.92 & 65.80 \\
Benzo(a)anthracene & 0.37 & 5.52 & 32.75 \\
Chrysene & 0.52 & 1.90 & 20.28 \\
Benzo(b)fluoranthene & 0.15 & 0.08 & 2.13 \\
Benzo(k)fluoranthene & 0.00 & 0.41 & 1.59 \\
Benzo(a)pyrene & 0.75 & 8.19 & 7.41 \\
Dibenzo(a,h)anthracene & 1.10 & 2.98 & 0.91 \\
Benzo(g,h,i)perylene & 6.46 & 7.78 & 3.75 \\
Indeno(1,2,3-cd)pyrene & 0.00 & 0.00 & 0.00 \\
\hline Summa PAH & 135.58 & 375.60 & 740.77 \\
\hline \hline
\end{tabular}

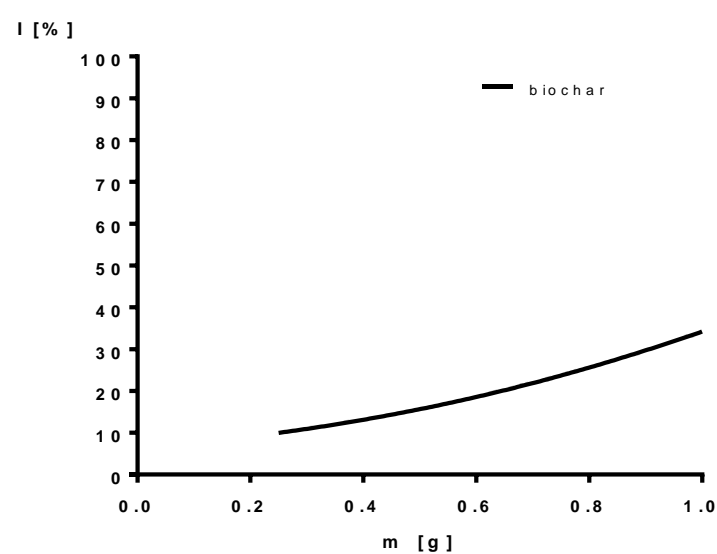

Fig. 1. Inhibition of seeds germination depends on biochar content.

Biochar $\mathrm{pH}$ was mildly alkaline and $\mathrm{pH}$ values were depended on different feedstock materials (Table I). The beech tree biochar contain the highest amount of PAHs (Table II). The most represented in the measured PAHs were naphthalene and phenathrene. Fluoranthrene, pyrene and fluorine were also significantly represented. Reference [12] 
published that the naphthalene was the most abundant individual PAH compound in all of the biochar matrices assessed. Also anthracene, fluoranthene and pyrene were the most often found compounds present in the biochar matrices. The amount and content of PAHS in biochar is strongly depending on temperature of pyrolization. From the measured heavy metals cadmium and lead were not detected. Iron was significantly increased in biochar from rice husks (Table I).

TABLE III: EC $_{50}$ VALUES

\begin{tabular}{llllll}
\hline \hline Cultivar & Metal & Bamboo & $\begin{array}{l}\text { Rice } \\
\text { husk }\end{array}$ & $\begin{array}{l}\text { Beech } \\
\text { tree }\end{array}$ & Control \\
\hline Expres & $\mathrm{Cd}$ & 4.816 & 2.763 & 6.498 & 0.877 \\
& $\mathrm{Cu}$ & 2.837 & 2.379 & 9.144 & 2.054 \\
& $\mathrm{~Pb}$ & 2.530 & 1.170 & 7.214 & 7.209 \\
Honey Graze & $\mathrm{Cd}$ & 12.03 & 6.141 & 18.34 & 0.929 \\
& $\mathrm{Cu}$ & 22.51 & 18.39 & 25.45 & 2.056 \\
& $\mathrm{~Pb}$ & 7.348 & 5.513 & 8.450 & 6.032 \\
Nutri Honey & $\mathrm{Cd}$ & 6.196 & 3.616 & 23.23 & 0.977 \\
& $\mathrm{Cu}$ & 5.886 & 2.290 & 7.201 & 2.033 \\
& $\mathrm{~Pb}$ & 1.097 & 3.889 & 7.221 & 5.884 \\
\hline \hline
\end{tabular}

The toxicity of biochar slightly increased with the amount of biochar in the medium (Fig. 1). The $\mathrm{IC}_{50}$ value was calculated on $20.8 \mathrm{~g}$ of biochar.

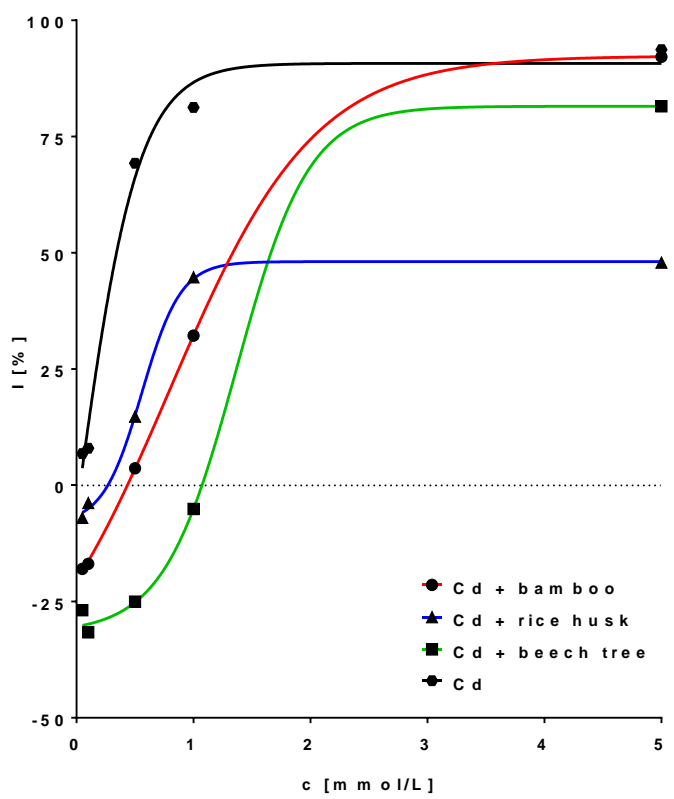

Fig. 2. Inhibition of sorghum seeds (cv. Nutri Honey) germination by cadmium in presence of different type of biochar.

Cadmium ion toxicity showed significant differences among the tested cultivars and especially between tested biochars. Beech tree biochar significantly decreased the toxicity of cadmium ions. Table III contained a list of $\mathrm{EC}_{50}$ values in wide range (from 2.76 to $23.23 \mathrm{mM}$ ) for the biochars compare to close range (from 0.887 to $0.977 \mathrm{mM}$ ) for the tested cultivars without biochar addition. In general, cadmium toxicity was high and biochar addition decreased the toxicity ten times (Fig. 2). Cadmium was probably adsorbed on the surface of particles of biochar and thus reduced the actual concentration of cadmium. The reduced availability was described [13]. In the presence of biochar reduced cadmium concentration in pore water more than ten times was detected.

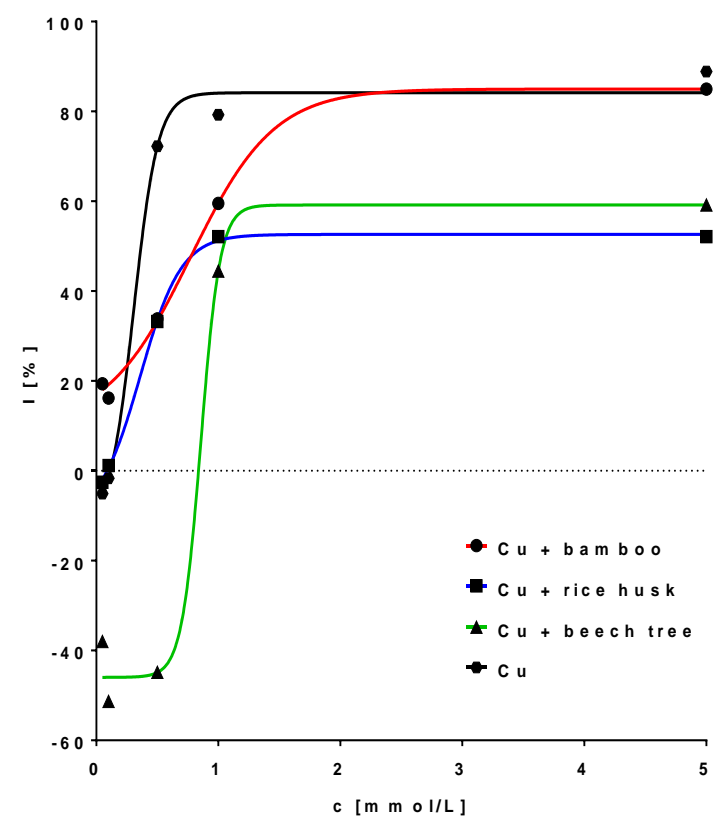

Fig. 3. Inhibition of sorghum seeds (cv. Nutri Honey) germination by copper in presence of different type of biochar.

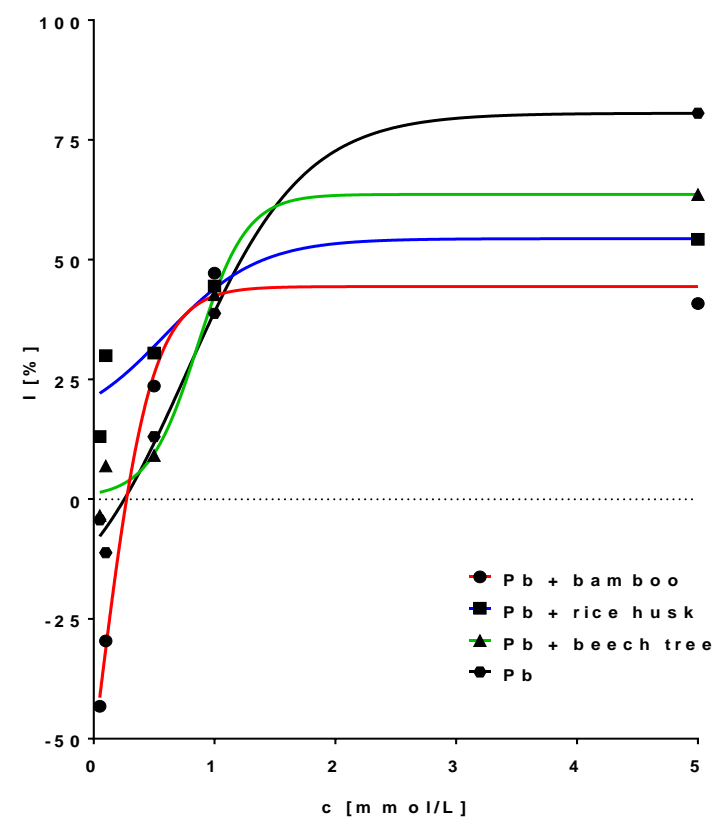

Fig. 4. Inhibition of sorghum seeds (cv. Nutri Honey) germination by lead in presence of different type of biochar.

In the case of copper, a wide range of $\mathrm{EC}_{50}$ values was observed for biochar addition and very close range for copper toxicity for different cultivars without biochar (Table III). Our results showed relatively low sorghum sensitivity to the presence of copper and biochar together, with the differences between cultivars being rather large. The beech tree biochar was the most efficient in copper toxicity reduction and even at low concentrations copper stimulated seeds germination. For other biochar types we obtained reduction toxicity in case of cultivar Honey Graze (Fig. 3). For cultivars Nutri Honey and especially for cultivar Expres the $\mathrm{EC}_{50}$ was close to $\mathrm{EC}_{50}$ values for copper without biochar. As was published in reference [13], copper concentrations in pore water increased 
after biochar addition and concentrations were significantly greater than in the control soil. Increased copper concentrations in pore water were associated with elevated concentrations of soluble organic carbon (DOC) from biochar. Associations between copper and DOC were previously found [14].

Slight stimulation of root growth was observed at a lead concentration $0.01 \mathrm{mM}$ with bamboo biochar addition. The $\mathrm{EC}_{50}$ values for lead ion in presence of biochar were found to be in the range of 1.10 to $8.45 \mathrm{mM}$. Cultivars showed a higher sensitivity to lead in presence of biochar than in its absence (Table III and Fig. 4). Lead is well known for its creation of insoluble compounds (i.e. with sulphate). Addition of biochar may cause better availability of lead due to an adsorption of lead ions to biochar particles. It was also reported that inactivated plant biochars can inadvertently increase dissolved lead and copper concentrations of sandy, low TOC soils and can be used to stabilize other contaminants [15]. These can explain the relatively high lead toxicity in presence of biochar.

\section{CONCLUSION}

Our results showed a high diversity in the response of sorghum cultivars to the presence of toxic metals. We found wide differences in toxicity for cultivars in the case of $\mathrm{Pb}^{2+}$, and high influence of biochar presence on heavy metal toxicity. The differences between types of biochar were also found. Differences determined between biochars were mainly in PAHs content and $\mathrm{pH}$. Our results proved the toxicity test is a useful tool for the testing of biochars suitable for phytoremediation and soil restoration purposes.

\section{ACKNOWLEDGMENT}

Authors thanks to Dr. Jing Song (Key Laboratory of Soil Environment and Pollution Remediation, Institute of Soil Science, Chinese Academy of Sciences, Nanjing, China) for providing biochar for experiments.

\section{REFERENCES}

[1] O. M. Saether, R. Krog, D. Segar, and G. Storroe, "Contamination of soil and ground water at former industrial site in Trondheim, Norway," Applied Geochemistry, vol. 12, pp. 327-332, 1997.

[2] P. Acero, J. M. A. Mandado, J. Gomez, M. Gimeno, L. Auque, and F. Torrijo, "Environmental impact of heavy metal dispersion in the Huerva River (Iberian range, NE Spain)," Environ. Geology, vol. 43, pp. 950-956, 2003.

[3] Z. Kafka and J. Punčochářová, "Těžké kovy v př́rodě a jejich toxicita," Chemické Listy, vol. 96, pp. 611-617, 2002.

[4] A. Fargašová, "Root growth inhibition, photosynthetic pigments production, and metal accumulation in Sinapis alba as the parameters for trace metals effects determination," Bulletin of Environmental Contamination and Toxicology, vol. 61, pp. 762-769, 1998.

[5] A. Fargašová and E. Beinrohr, "Metal-metal interaction in accumulation of $\mathrm{V}^{5+}, \mathrm{Ni}^{2+}, \mathrm{Mo}^{6+}, \mathrm{Mn}^{2+}$ and $\mathrm{Cu}^{2+}$ in under- and above-ground parts of Sinapis alba," Chemosphere, vol. 36, no. 6, pp. 1305-1317, 1998.

[6] A. Fargašová, "Determination of metal interactions on root growth of Sinapis alba seedlings," Biologia Plantarum, vol. 42, no. 4, pp. 637-640, 1999.

[7] Z.-T. Xiong, "Lead uptake and effects on seed germination and plant growth in a $\mathrm{Pb}$ hyperaccumulator Brassica pekinensis Rupr," Bulletin of Environmental Contamination and Toxicology, vol. 60, pp. 285-291, 1998.

[8] A. Fargašová, "Phytotoxic effects of $\mathrm{Cd}, \mathrm{Zn}, \mathrm{Pd}, \mathrm{Cu}$ and $\mathrm{Fe}$ on Sinapis alba L. seedlings and their accumulation in roots and shoots," Biologia Plantarum, vol. 44, no. 3, pp. 471-473, 2001.

[9] J. R. Peralta, J. L. Gardea-Torresdey, K. J. Tiemann, E. Gomez, S. Arteaga, E. Rascon, and J. G. Parsons, "Uptake and effects of five heavy metals on seed germination and plant growth in alfalfa (Medicago sativa L.)," Bulletin of Environmental Contamination and Toxicology, vol. 66, pp. 727-734, 2001.

[10] O. Munzuroglu and H. Geckil, "Effects of metals on seed germination, root elongation, and coleoptile and hypocotyl growth in Triticum aestivum and Cucumis sativus," Archives of Environmental Contamination and Toxicology, vol. 43, pp. 203-213, 2002.

[11] F. Zhao, S. P. McGrath, and A. R. Crosland, "Comparison of three wet digestion methods for the determination of plant sulfur by inductively-coupled plasma-atomic emission-spectroscopy (ICP-AES)," Commun. Soil Sci. Plan., vol. 25, pp. 407-418, 1994.

[12] A. Freddo, C. Cai, and B. J. Reid, "Environmental contextualisation of potential toxic elements and polycyclic aromatic hydrocarbons in biochar," Environmental Pollution, vol. 171, pp. 18-24, 2012.

[13] L. Beesley, E. Moreno-Jiménez, and J. L. Gomez-Eyles, "Effects of biochar and greenwaste compost amendments on mobility, bioavailability and toxicity of inorganic and organic contaminants in a multi-element polluted soil," Environmental Pollution, vol. 158, pp. 2282-2287, 2010.

[14] M. P. Bernal, R. Clemente, and D. J. Walker, "Interactions of heavy metals with soil organic matter in relation to phytoremediation," in Phytoremediation: the Green Salvation of the World, J. P. Navarro-Aviño, Ed. Kerala, India: Research Signpost, 2009, pp. 109-129.

[15] M. Uchimiya and D. I. Bannon, "Solubility of lead and copper in biochar-amended small arms range soils: Influence of soil organic carbon and pH," J. Agric. Food Chem., vol. 61, no. 32, pp. 7679-7688, 2013.

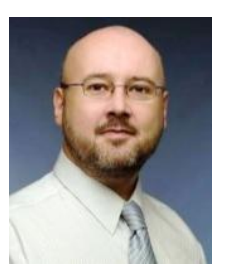

Petr Soudek was born on March 16, 1971 in Vsetin, Czech Republic. He graduated from the Faculty of Science, Charles University, Department of Biochemistry in 1995 and the Catholic Theological Faculty of Charles University in 1998. At the Faculty of Science, he developed the thesis on the topic: Characterization of factors influence of peroxidase production by culture of horseradish (Armoracia rusticana L.) cultivated in vitro. In 2004 he obtained the Ph.D. degree at the Department of Anatomy and Physiology, Faculty of Science, Charles University and he defended dissertation on the topic: Study of accumulation toxic metals and radionuclides by higher plants and its potential utilization for phytoremediation.

Since 1994 he had been employed as a researcher at the Department of Plant Tissue Cultures, Institute of Organic Chemistry and Biochemistry AS CR, and later, since 2007, he has been working in the Laboratory of Plant Biotechnology, Institute of Experimental Botany AS CR. Since 2006 he has been the deputy head of the laboratory. Within the Czech-German bilateral cooperation he stayed in Leipzig and Sythen at BioPlanta, GmbH. In 2003, he received a two months fellowship at ARI The Jacob Blaustein Institute for Desert Research, Ben-Gurion University of the Negev, Sede Boqer in Israel. In 2009, he completed a monthly study intership at the Helmholtz Zentrum München, Deutsches Forschungszentrum für Gesundheit und Umwelt $(\mathrm{GmbH})$ in Germany.

Dr. Soudek is a member of the International Society Phytotechnology and Asia-Pacific Chemical, Biological \& Environmental Engineering Society. He was awarded for the best posters on Workshop of COST Action 837 (2002), 9th FECS Conference and 2nd SFC Meeting on Chemistry and the Environment (2004), and on International Symposium on Environmental Biotechnology (2006) and for the best conference presentation on 3rd International Conference on Biology, Environment and Chemistry (2012) and on 3rd International Conference on Energy and Environmental Science (2013). He is the author of 37 impacted publications and he is involved as the principal investigator in many national and international projects. He is also a member of the Kladno City Local Government and a member of an environment committee of city council. 